\title{
Udder health of early-lactation primiparous dairy cows based on somatic cell count categories
}

\author{
K. Persson Waller, ${ }^{1,2 *}$ (1) A. Lundberg, ${ }^{3}$ and A.-K. Nyman ${ }^{2,3}$ (이 \\ ${ }^{1}$ Department of Animal Health and Antimicrobial Strategies, National Veterinary Institute (SVA), SE-751 89 Uppsala, Sweden \\ ${ }^{2}$ Department of Clinical Sciences, Swedish University of Agricultural Sciences (SLU), SE-750 07 Uppsala, Sweden \\ ${ }^{3}$ Växa Sverige, SE-104 25 Stockholm, Sweden
}

\section{ABSTRACT}

The aims were to investigate the prevalence of intramammary infection in early-lactation primiparous dairy cows $(\mathrm{PC})$ in Sweden using milk recording cow composite somatic cell count (CSCC) categories based on classification of CSCC at the first 2 milk recordings after calving as low or high using cut-offs indicating intramammary infection. We also wanted to evaluate if herd-specific patterns in CSCC categories among PC can be identified to indicate success and problem herds as well as cow-level associations between CSCC categories and breed and sire, and herd-level associations between CSCC categories and herd size, milk production, production system, milking system, and year. A total of 1,597 dairy herds were included. Inclusion criteria were enrolment in the Swedish official milk recording scheme and having production data from at least 10 PC per year during 2014, 2015, and 2016. Herd (size, SCC, milk production, production system, milking system) and cow (breed, lactation number, calving date, CSCC, milk production) data were collected from the Swedish official milk recording scheme. Each PC was assigned a CSCC category (low-low, low-high, highhigh, high-low, or inconclusive) based on the CSCC at the first 2 milk recordings using the following cutoffs. At each milk recording a CSCC $\leq 75,000$ cells/ $\mathrm{mL}$ was considered low and a CSCC $>100,000$ cells/ $\mathrm{mL}$ was considered high, whereas a CSCC in between those values was considered inconclusive. Associations between CSCC categories and breed or sire of the PC were analyzed using multivariable multinomial logistic regression models. Associations at herd level between number of PC in a CSCC category and herd variables were analyzed using multivariable Poisson or negative binomial regression models. The annual proportions of CSCC categories for all PC were 51.3\%, 5.5\%, 15.5\%, $13.7 \%$, and $14.0 \%$ for the low-low, low-high, high-low,

Received February 11, 2020.

Accepted June 3, 2020.

*Corresponding author: karin.persson-waller@sva.se high-high, and inconclusive categories, respectively. The distribution of CSCC categories varied markedly between herds. Overall, the median herd prevalence was 50.2 to $54.2 \%$ and 11.7 to $13.2 \%$ per year for the lowlow and high-high categories, respectively. At cow level, both breed and sire were significantly associated with CSCC categories, showing for example that a higher proportion of Jersey PC were categorized as high-high compared with Swedish Holstein (SH) and Swedish Red (SR) PC, and that PC of certain SH and SR sires more often were categorized as low-low or high-high cows than PC of other sires within each breed. All herd factors, except conventional and organic production, were significantly associated with the proportion of $\mathrm{PC}$ in a CSCC category at herd level. For example, the proportion of PC in the low-low category was significantly lower in larger herds ( $\geq 80$ cows) compared with smaller herds ( $<80$ cows) and significantly lower in automatic milking system herds than in herds with other milking systems, but significantly higher in herds with higher milk production. Overall, the results indicate a substantial need for prevention of subclinical mastitis in early-lactation PC as only $50 \%$ of these cows had low CSCC at both milk recordings after calving. Moreover, we conclude that CSCC categories may be a useful tool for identifying success and problem herds.

Key words: mastitis, somatic cell count categories, breed, sire, herd size

\section{INTRODUCTION}

Primiparous cows are an important part of the dairy industry. In Sweden, around $36 \%$ of the dairy cows are primiparous (Anonymous, 2016, 2017a). Mastitis is an important disease affecting dairy cows worldwide resulting in negative effects on animal welfare and substantial costs for the industry especially when cows are affected early in lactation (Hagnestam et al., 2007). Studies from Sweden (e.g., Svensson et al., 2006; Nyman et al., 2009; Frössling et al., 2017) and other countries (e.g., review by De Vliegher et al., 2012, includes studies until 2010; Santman-Berends et al., 2012; 
Bludau et al., 2014; Naqvi et al., 2018) have found that it is not uncommon for primiparous cows to have clinical or subclinical mastitis already during the first week or month of lactation, which may have severe effects on the productive life of these cows. Overall, mastitis is more common in multiparous cows than in primiparous cows, but several studies have found the opposite during the first week or month of lactation (Nyman et al., 2007; Olde Riekerink et al., 2007; Frössling et al., 2017). The mastitis-causing pathogens found in primiparous cows are similar to those of older cows, but non-aureus staphylococci are, in general, more common in primiparous cows (Fox, 2009; De Vliegher et al., 2012). Although several cow- and herd-level risk factors for mastitis in primiparous cows have been identified (Fox, 2009; De Vliegher et al., 2012), the continued occurrence of both clinical and subclinical mastitis in these cows indicates that more effort is needed to prevent this disease.

The cow composite milk somatic cell count (CSCC), analyzed in milk samples collected at monthly milk recordings in farms affiliated to a milk recording scheme, is often used as an indicator of subclinical mastitis or IMI. Compared with other inflammatory markers, the CSCC is considered as the best indicator of IMI ( $\mathrm{Ny}-$ man et al., 2016). Thus, the CSCC is a reliable and easily available tool for studies on udder health. In line with this, Lundberg et al. (2016) found that the CSCC at the first milk recording after calving is a good indicator of IMI at calving or within $4 \mathrm{~d}$ of calving.

The results of our previous study (Lundberg et al., 2016) also indicated differences between farms in prevalence of IMI in primiparous cows at or just after calving, indicating that herd factors are of importance. However, as that study only included a small number of farms, a larger national study evaluating cow and herd prevalence of early-lactation subclinical mastitis in primiparous cows is warranted. If farms with a low or high risk of such problems can be identified, studies on risk and success factors can be initiated.

The main aim of the study was to investigate the prevalence of mastitis in early-lactation primiparous cows in Sweden using milk recording CSCC categories based on the classification of CSCC at the first 2 monthly milk recordings after calving as low or high using cut-offs indicating noninfected and infected primiparous cows, respectively. Moreover, we also wanted to study associations between the CSCC categories and the cow factors breed and sire. Another aim was to evaluate if herd-specific stable patterns in CSCC categories among primiparous cows can be identified to indicate success and problem herds. If so, such herds can be used in studies on risk factors for mastitis. Finally, associations between herd size, herd milk production, production system (organic or conventional), milking system and year, and herd-level CSCC categories were also investigated.

\section{MATERIALS AND METHODS}

\section{Herd Selection}

All herds affiliated to the Swedish official milk recording scheme (SOMRS) 2014-2016 $(\mathrm{n}=3,068,2,783$, and 2,577 herds for 2014, 2015, and 2016, respectively) were eligible for the study. Among those, all herds with production data from all $3 \mathrm{yr}$ and at least 10 primiparous cows per year with their first milk recording 5 to $35 \mathrm{~d}$ after calving and their second milk recording 20 to $40 \mathrm{~d}$ after the first milk recording for each of the $3 \mathrm{yr}$ were selected, resulting in a total of 1,597 herds.

\section{Data Collection and Editing}

Cow data on breed, lactation number, calving dates of cows, and milk recording data on CSCC and milk production were collected from the SOMRS for selected herds. Information on annual herd size, milk SCC, and milk production, as well as production and milking systems, were generated from the same sources.

The CSCC data for primiparous cows with their first milk recording 5 to $35 \mathrm{~d}$ after calving and their second milk recording 20 to $40 \mathrm{~d}$ after the first milk recording were identified. Based on the CSCC from the 2 milk recordings, each primiparous cow was assigned a CSCC category (low-low, low-high, high-high, high-low, or inconclusive) based on the following cut-offs. At each milk recording a CSCC $\leq 75,000$ cells $/ \mathrm{mL}$ was considered low and a CSCC $>100,000$ cells $/ \mathrm{mL}$ was considered high. If the CSCC was in between those values at one or both milk recordings, the cow was assigned the category inconclusive. The selection of CSCC cutoffs was based on results from our previous studies (Svensson et al., 2006; Nyman et al., 2009; Nyman et al., 2014; Lundberg et al., 2016) on CSCC at first and second milk recording after calving for noninfected and infected cows.

\section{Statistical Analyses}

All statistical analyses were performed using Stata (release 15.1; StataCorp LLC, College Station, TX).

Cow Level. Descriptive statistics on CSCC for the first and second milk recording and the proportion of primiparous cows in the 5 CSCC categories were calculated for 2014, 2015, and 2016. To investigate if there were significant differences in CSCC between the first and second milk recording within year, as well as for 
first or second milk recordings, respectively, between years $(2014,2015,2016)$, the paired $t$-test was used.

Associations between CSCC categories and breed [Swedish Red (SR), Swedish Holstein (SH), Jersey, $\mathrm{SR} \times \mathrm{SH}$ crosses, $\mathrm{SR}$ cross breeds, $\mathrm{SH}$ cross breeds, other breeds] were investigated using a multivariable multinomial logistic regression model (using the mlogit command in Stata), with CSCC categories (low-low, low-high, high-high, high-low, or inconclusive) as the dependent variable and breed as the explanatory variable, also including age at calving, DIM at first milk recording, and year and month of first milk recording as explanatory variables (to adjust for those effects on CSCC), adjusting for clustering within herd (using the cluster option in Stata that reports standard errors that allow for intragroup correlation). The models were built using a manual stepwise, backward variable selection procedure where the initial model included all independent variables as main effects. Variables with a significant association $(P \leq 0.05)$ with the dependent variable were kept in the models. Moreover, collinearity between variables was tested for all multivariable models by calculations of Spearman rank correlations. If variables showed collinearity $(r>0.7)$, only the variable with the lowest $P$-value in the univariable analysis was kept in the model. All plausible 2-way interactions between the main effects significant in the model were investigated.

To investigate if choice of breeding sire of the primiparous cows was associated with CSCC categories, 2 separate multinomial logistic regression models adjusting for cluster within herd were used for primiparous cows of SR or SH breed, separately, only including sires fathering $\geq 1,000$ primiparous cows in the present data. In total, 3,872 sires were found in the data set, but only 16 ( $8 \mathrm{SH}, 7 \mathrm{SR}$, and 1 Danish Red) had sired $\geq 1,000$ primiparous cows.

Herd Level. For each herd and study year, the proportion of primiparous cows in the 5 CSCC categories was calculated. Then, descriptive statistics of the distribution of CSCC categories for all herds included in the study were generated as well as within-herd pattern of CSCC categories.

Associations between number of primiparous cows with a certain CSCC category and herd characteristics \{milking system [automatic milking system (AMS), parlor, rotary, tiestall milking], conventional or organic production, herd size (annual number of cows), herd milk production ( $\mathrm{kg}$ of $\mathrm{ECM}$ ), and year (2014, 2015, and 2016) $\}$ were investigated using multivariable mixedeffect Poisson or negative binomial regression models, adjusted for repeated measurements within herd. The total number of primiparous cows with a CSCC category in each herd was used as exposure. The models were built using a manual stepwise, backward variable selection procedure where the initial model included all independent variables as main effects. Variables with a significant association $(P \leq 0.05)$ with the dependent variable were kept in the models. Before entering the model, continuous variables were assessed if they were linearly related to the outcome, and if not, they were categorized using percentiles as cut-offs. Moreover, collinearity between variables was tested for all multivariable models, by calculations of Spearman rank correlations. If variables showed collinearity $(\mathrm{r} \geq 0.7)$, only the variable with the lowest $P$-value in the univariable analysis was kept in the model. All plausible 2-way interactions between the main effects significant in the model were investigated. The overall effect of each main effect included in each final model was investigated postregression using Wald's test (the test command in Stata), specifying the Bonferroni's method for adjusting $P$-values for multiple testing [the mtest (Bonferroni) option in Stata]. The model fit was assessed visually by inspecting plots of residuals according to Dohoo et al. (2010). If divergent observations were found, models were rerun without these observations to assess the effect of these observations. If the coefficients did not change or only marginally changed ( $<5 \%$ difference), the original model was kept.

To estimate how stable the proportion of primiparous cows with a specific CSCC category was on the herd level, the coefficient of variation (CV) was calculated for each SCC category and herd over the $3 \mathrm{yr}$.

\section{RESULTS}

\section{Basic Herd and Cow Data}

In total, 1,597 herds were included in the study. Information on numbers of cows, milk production, and SCC at herd level is given in Table 1. According to data from the milk and health recording schemes, $63 \%$ of the herds included in the study had loose housing systems (mainly freestalls) and 37\% had tiestalls. Moreover, $33 \%$ milked their cows using AMS and 33\% using tiestall milking, whereas the remaining herds used a milking parlor or rotary. Fifteen percent of the farms had organic production, whereas $85 \%$ had conventional production.

The number of primiparous cows present in the data set was $51,821,52,080$, and 51,326 for 2014,2015 , and 2016, respectively. The mean [median; interquartile range (IQR)] number of primiparous cows with data from the first 2 milk recordings after calving per herd was $32(25 ; 17-38), 33(24 ; 17-38)$, and 32 (24; 16-38) for 2014, 2015, and 2016, respectively. These cows represented on average (median; IQR) $80 \%$ (83\%; 
Table 1. Herd size, milk production, and bulk milk SCC (BMSCC; × 1,000 cells/mL) for 1,597 herds included in the study for the years of selection

\begin{tabular}{lccc}
\hline Variable $^{1}$ & 2014 & 2015 & 2016 \\
\hline Cow numbers & 108 & 110 & 111 \\
Mean & 79 & 80 & 81 \\
Median & $(60 ; 131)$ & $(60 ; 134)$ & $(60 ; 134)$ \\
$\quad(50 \%$ IQR $)$ & 9,878 & 10,040 & 10,254 \\
kg of ECM & 9,936 & 10,128 & 10,327 \\
Mean & $(9,238-10,585)$ & $(9,373-10,762)$ & $243-11,017)$ \\
Median & & & 243 \\
$\quad(50 \%$ IQR $)$ & 244 & 243 & $(187-293)$ \\
BMSCC & 238 & 234 & $(189-288)$ \\
Mean & $(187-293)$ & & \\
Median & (50\% IQR) & &
\end{tabular}

${ }^{1} \mathrm{IQR}=$ interquartile range. $\mathrm{SCC}$ calculated based on milk recording data.

$72-91), 80 \%$ (84\%; 72-91), and $78 \%(82 \% ; 69-90)$ of all primiparous cows per herd in 2014, 2015, and 2016, respectively. The mean (median; IQR) DIM at first and second milk recordings for all years were $19(19 ; 12-26)$ and $49(49 ; 42-57)$, respectively, and the mean (median; IQR) CSCC at first and second milk recordings for all years were $205,000(58,000 ; 32,000-135,000)$ and $130,000(37,000 ; 21,000-84,000)$ cells/mL, respectively.

\section{Cow Level: Primiparous Cow CSCC and CSCC Categories}

Descriptive statistics on the CSCC of all primiparous cows included in the study are given in Table 2. The mean CSCC was significantly higher at the first milk recording compared with the second milk recording, and this was consistent for all years $(P<0.0001)$. The mean CSCC at first and second milk recording was significantly higher in year 2014 compared with first and second milk recording in 2015 and $2016(P<0.0001)$, and in 2015 compared with $2016(P<0.0001)$.

The annual proportion of primiparous cows in the 5 CSCC categories is given in Figure 1. For each year, more than $85 \%$ of those cows were allocated to a CSCC category. Approximately 50 to $53 \%$ of the cows were in the low-low category and 13 to $14.5 \%$ were in the high-high category, indicating good and poor udder health, respectively. In comparison, $5.5 \%, 15.5 \%$, and $14.0 \%$ were in the low-high, high-low, and inconclusive category, respectively.

\section{Cow Level: Associations Between CSCC Categories and Breed}

The distribution of primiparous cows within each CSCC category varied between breeds (Table 3 ). Cows of the $\mathrm{SH}$ breed had the highest proportion of primiparous cows in the low-low category $(52.1 \%)$, whereas
Jersey cows had the lowest proportion (39.1\%). The proportion of cows in the low-high $(5.3-6.1 \%)$, high-low (14.1-16.1\%), and inconclusive (13.0-17.1\%) categories varied less between breeds. The Jersey breed had the highest proportion of primiparous cows in the highhigh category $(21.3 \%)$, whereas cows of the SH breed had the lowest proportion (12.5\%).

The predicted probabilities from the regression model are presented in Figure 2, showing, for example, the lower probability of being a cow in the low-low category and the higher probability of being in the high-high or inconclusive category if the cow is of Jersey breed.

Most of the numerical differences in proportion of cows of different breed within the CSCC categories were also confirmed to be significant in the multivariable multinomial logistic regression analysis. Detailed results are given in Supplemental Data S1 and Table S1; https://doi.org/10.3168/jds.2020-18346. For example, the relative risk ratio of being a primiparous cow in the high-high category compared with a primiparous cow in the low-low category increased significantly if

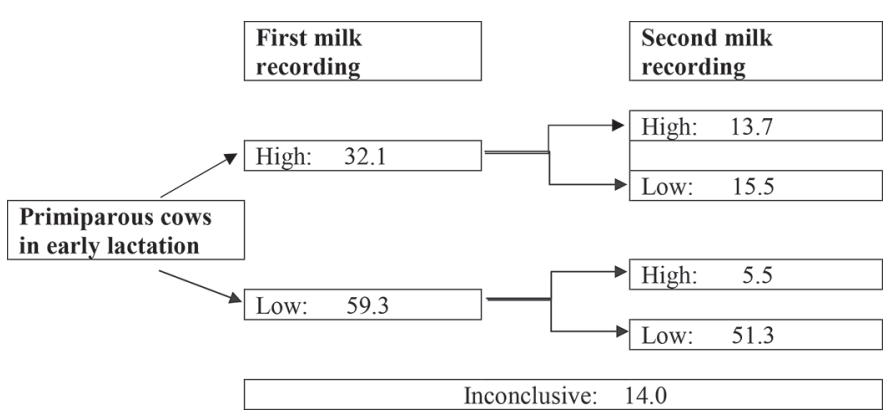

Figure 1. Mean distribution (\%) of primiparous cows based on cow composite SCC at the first and second monthly milk recording after calving in years 2014-2016 (mean $=62,233$ cows $/$ year). Low $=$ $<75,000$ cells $/ \mathrm{mL}$; high $=>100,000$ cells $/ \mathrm{mL}$; inconclusive $=\mathrm{SCC}$ in between low and high in one or both of the 2 first monthly milk recordings after calving. 
Table 2. Descriptive statistics of cow composite milk SCC $(\times 1,000 / \mathrm{mL})$ at the first and second monthly milk recording after calving in primiparous cows from 1,597 herds for each year of the study

\begin{tabular}{|c|c|c|c|c|c|c|}
\hline \multirow[b]{2}{*}{ Variable $^{1}$} & \multicolumn{2}{|c|}{$\begin{array}{c}2014 \\
(\mathrm{n}=51,821)\end{array}$} & \multicolumn{2}{|c|}{$\begin{array}{c}2015 \\
(\mathrm{n}=52,080)\end{array}$} & \multicolumn{2}{|c|}{$\begin{array}{c}2016 \\
(\mathrm{n}=51,326)\end{array}$} \\
\hline & First & Second & First & Second & First & Second \\
\hline $\begin{array}{l}\text { Mean (A) } \\
\text { (SD) }\end{array}$ & $\begin{array}{c}215 \\
(647)\end{array}$ & $\begin{array}{c}133 \\
(441)\end{array}$ & $\begin{array}{c}199 \\
(588)\end{array}$ & $\begin{array}{c}131 \\
(446)\end{array}$ & $\begin{array}{c}199 \\
(631)\end{array}$ & $\begin{array}{c}126 \\
(443)\end{array}$ \\
\hline Mean (G) & 75 & 50 & 73 & 48 & 69 & 45 \\
\hline$(95 \%$ CI $)$ & $(75-77)$ & $(49-50)$ & 73-74) & $(47-48)$ & $(69-70)$ & $(45-46)$ \\
\hline Median & 60 & 39 & 59 & 38 & 55 & 35 \\
\hline (50\% IQR) & $(33-140)$ & $(22-88)$ & $(32-135)$ & $(21-84)$ & $(30-127)$ & $(20-79)$ \\
\hline
\end{tabular}

${ }^{1} \mathrm{~A}=$ arithmetic; $\mathrm{G}=$ geometric; $\mathrm{IQR}=$ interquartile range.

the cow was SR, Jersey, SR $\times \mathrm{SH}$, SR cross breed or of other breeds compared with SH. Moreover, the relative risk ratio of being a primiparous cow in the highhigh category compared with a primiparous cow in the low-low category increased significantly if the cow was Jersey or of other breeds compared with SR, of other breeds compared with $\mathrm{SR} \times \mathrm{SH}$, or of other breeds compared with SR cross breed.

\section{Cow Level: Associations Between CSCC Categories and Sire for Primiparous Cows of the SR Breed}

The $7 \mathrm{SR}$ sires (SR_1 to $\mathrm{SR} \_7$ ) that had sired $\geq 1,000$ primiparous cows each were used in the analysis of association between sire and CSCC category of primiparous cows. The distribution of primiparous cows with different CSCC categories within sire is presented in Table 4. Sire SR_3 had the highest proportion of primiparous cows in the low-low CSCC category $(60.9 \%)$, whereas sire SR_1 had the highest proportion of primiparous cows in the high-high CSCC category (16.8\%).

The predicted probabilities from the regression model are presented in Figure 3, showing, for example, the higher probability of being a primiparous cow in the low-low category and the lower probability of being in the high-high or inconclusive category if the sire was SR_3.

The multivariable multinomial logistic regression analysis showed significant differences in distribution of primiparous cows in the different CSCC categories between SR sires. Detailed results are given in Supplemental Data S2 and Table S2 (https://doi.org/10.3168/ jds.2020-18346). For example, the relative risk ratio of being a primiparous cow in the high-high category compared with a primiparous cow in the low-low category decreased significantly if the sire was SR_3 compared with the other sires, or if the sire was SR_4 compared with SR_1, SR_2, SR_5, or SR_7. Moreover, the risk

Table 3. Distribution of primiparous cows [number (n) and proportions (\%) within breed] categorized depending on their cow composite somatic cell count (CSCC) at the first and second monthly milk recording after calving within the Swedish Red (SR) breed, Swedish Holstein (SH) breed, Jersey (Jer), cross breeds between SR and SH $(\mathrm{SR} \times \mathrm{SH})$, cross breeds between SR and other breeds (SR cross), cross breeds between $\mathrm{SH}$ and other breeds (SH cross), and all other pure breeds and cross breeds (other)

\begin{tabular}{|c|c|c|c|c|c|c|c|}
\hline \multirow[b]{2}{*}{ Breed } & & \multicolumn{6}{|c|}{ CSCC category } \\
\hline & & Low-Low & Low-High & High-Low & High-High & Inconclusive & Total \\
\hline \multirow[t]{2}{*}{ SR } & $\mathrm{n}$ & 23,041 & 2,499 & 6,435 & 6,795 & 6,562 & 45,232 \\
\hline & $\%$ & 50.9 & 5.5 & 14.2 & 15.0 & 14.3 & 100.0 \\
\hline \multirow[t]{2}{*}{$\mathrm{SH}$} & $\mathrm{n}$ & 41,638 & 4,312 & 12,957 & 9,997 & 11,056 & 79,960 \\
\hline & $\%$ & 52.1 & 5.4 & 16.2 & 12.5 & 13.8 & 100.0 \\
\hline \multirow[t]{2}{*}{ Jer } & $\mathrm{n}$ & 405 & 61 & 172 & 220 & 177 & 1,035 \\
\hline & $\%$ & 391 & 5.9 & 16.2 & 21.3 & 17.1 & 100.0 \\
\hline \multirow[t]{2}{*}{$\mathrm{SR} \times \mathrm{SH}$} & $\mathrm{n}$ & 2,884 & 321 & 886 & 805 & 799 & 5,792 \\
\hline & $\%$ & 50.6 & 5.6 & 15.6 & 14.1 & 14.0 & 100.0 \\
\hline \multirow[t]{2}{*}{ SR cross } & $\mathrm{n}$ & 3,710 & 378 & 1,040 & 1,035 & 1,005 & 7,168 \\
\hline & $\%$ & 51.8 & 5.3 & 14.5 & 14.4 & 14.0 & 100.0 \\
\hline \multirow[t]{2}{*}{$\mathrm{SH}$ cross } & $\mathrm{n}$ & 233 & 29 & 78 & 75 & 62 & 477 \\
\hline & $\%$ & 48.8 & 6.1 & 16.3 & 15.7 & 13.0 & 100.0 \\
\hline \multirow[t]{2}{*}{ Other } & $\mathrm{n}$ & 5,811 & 731 & 2,015 & 1,984 & 1,790 & 12,331 \\
\hline & $\%$ & 47.1 & 5.9 & 16.3 & 16.1 & 14.5 & 100.0 \\
\hline \multirow[t]{2}{*}{ Total } & $\mathrm{n}$ & 77,722 & 8,331 & 23,583 & 20,911 & 21,351 & 151,898 \\
\hline & $\%$ & 51.3 & 5.5 & 15.5 & 13.7 & 14.0 & 100.0 \\
\hline
\end{tabular}



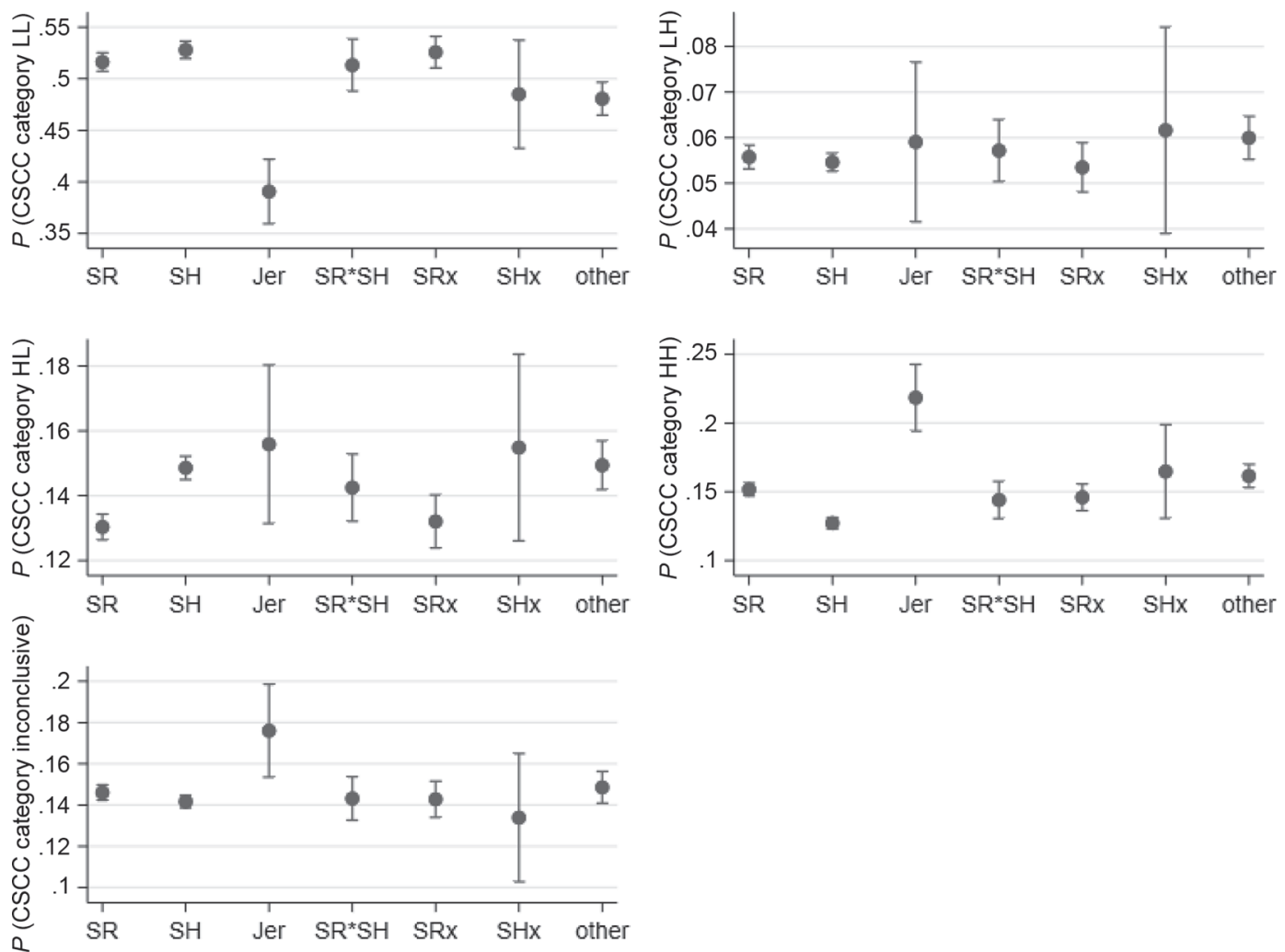

Figure 2. Predicted probabilities with 95\% CI (crossbars) for primiparous cows of different breeds [Swedish Red (SR) breed, Swedish Holstein $(\mathrm{SH})$ breed, Jersey (Jer), cross breeds between SR and SH (SR $\times \mathrm{SH})$, cross breeds between SR and other breeds (SRx), cross breeds between SH and other breeds (SHx) and all other pure breeds and cross breeds (other)] of being in a low-low (LL), low-high (LH), high-low (HL), high-high (HH), or inconclusive cow composite somatic cell count (CSCC) category, based on results from the 2 first monthly milk recordings after calving ( $\mathrm{n}=151,898$ primiparous cows in 1,597 herds).

Table 4. Distribution of primiparous cows [numbers (n) and percentages within sire], categorized into low-low, low-high, high-low, high-high, and inconclusive categories, depending on their cow composite somatic cell count (CSCC) at the first and second monthly milk recording after calving, within 7 sires (SR_1 to SR_7) of the Swedish Red (SR) breed, only including offspring from bulls that sired $\geq 1,000$ primiparous cows in the data set

\begin{tabular}{|c|c|c|c|c|c|c|c|}
\hline \multirow[b]{2}{*}{ Sire } & & \multicolumn{6}{|c|}{ CSCC category } \\
\hline & & Low-Low & Low-High & High-Low & High-High & Inconclusive & Total \\
\hline \multirow[t]{2}{*}{$\overline{S R \_1}$} & $\mathrm{n}$ & 1,292 & 119 & 408 & 445 & 378 & 2,642 \\
\hline & $\%$ & 48.9 & 4.5 & 15.4 & 16.8 & 14.3 & 100.0 \\
\hline \multirow[t]{2}{*}{ SR $\_2$} & $\mathrm{n}$ & 573 & 66 & 193 & 180 & 231 & 1,243 \\
\hline & $\%$ & 46.1 & 5.3 & 15.5 & 14.5 & 18.6 & 100.0 \\
\hline \multirow[t]{2}{*}{$S R \_3$} & $\mathrm{n}$ & 616 & 54 & 135 & 92 & 115 & 1,012 \\
\hline & $\%$ & 60.9 & 5.3 & 13.3 & 9.1 & 11.4 & 100.0 \\
\hline \multirow[t]{2}{*}{ SR_4 } & $\mathrm{n}$ & 1,072 & 95 & 284 & 240 & 337 & 2,028 \\
\hline & $\%$ & 52.9 & 4.7 & 1,408 & 11.8 & 16.6 & 100.0 \\
\hline \multirow[t]{2}{*}{ SR_5 } & $\mathrm{n}$ & 745 & 79 & 221 & 248 & 235 & 1,528 \\
\hline & $\%$ & 48.8 & 5.2 & 14.5 & 16.2 & 15.4 & 100.0 \\
\hline \multirow[t]{2}{*}{ SR $\_6$} & $\mathrm{n}$ & 1,016 & 109 & 270 & 271 & 266 & 1,932 \\
\hline & $\%$ & 52.6 & 5.6 & 14.0 & 14.0 & 13.8 & 100.0 \\
\hline \multirow[t]{2}{*}{ SR_7 } & $\mathrm{n}$ & 910 & 111 & 288 & 304 & 311 & 1,924 \\
\hline & $\%$ & 47.3 & 5.8 & 15.0 & 15.8 & 16.2 & 100.0 \\
\hline \multirow[t]{2}{*}{ Total } & $\mathrm{n}$ & 6,224 & 633 & 1,799 & 1,780 & 1,873 & 12,309 \\
\hline & $\%$ & 50.6 & 5.1 & 14.6 & 14.5 & 15.2 & 100.0 \\
\hline
\end{tabular}



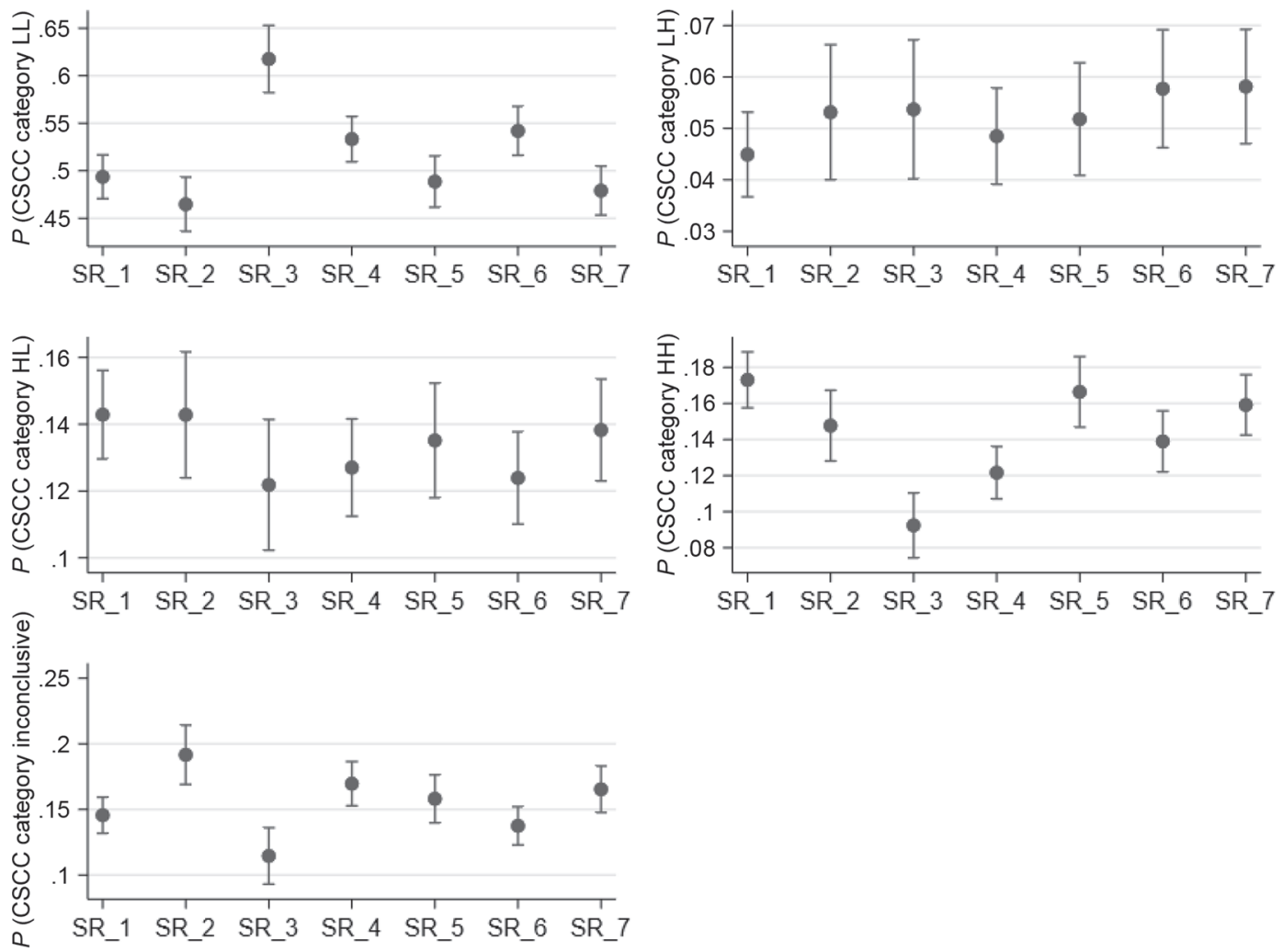

Figure 3. Predicted probabilities with 95\% CI (crossbars) for primiparous cows of 7 different sires of the Swedish Red (SR_1 to SR_7) breed of being in a low-low (LL), low-high (LH), high-low (HL), high-high (HH), or inconclusive composite somatic cell count (CSCC) category, based on results from the 2 first monthly milk recordings after calving ( $\mathrm{n}=12,309$ first-parity cows in 1,211 herds). Only sires with $\geq 1,000$ offspring in the data used were included in the analysis.

ratio decreased if the sire was SR_6 compared with SR_1, SR_5, or SR_7.

\section{Cow Level: Associations Between CSCC Categories and Sire for Primiparous Cows of the SH Breed}

The 8 SH sires (SH_1 to SH_8) that had sired $\geq 1,000$ primiparous cows each were used in the analysis of association between sire and CSCC category of primiparous cows. The distribution of primiparous cows with different CSCC categories within sire is presented in Table 5. Sire SH_8 had the highest proportion of primiparous cows in the low-low CSCC category (62.2\%), whereas sire SH_1 had the highest proportion of primiparous cows in the high-high CSCC category (20.2\%).

The predicted probabilities from the regression model are presented in Figure 4, showing, for example, the higher probability of being a primiparous cow in the low-low category if the sire was SH_8 and the higher probability of being in the high-high category if the sire was SH_1 or SH_6.
The multivariable multinomial logistic regression analysis showed significant differences in distribution of primiparous cows in the different CSCC categories between SH sires. Detailed results are given in Supplemental Data S3 and Table S3 (https://doi.org/10.3168/ jds.2020-18346). For example, the relative risk ratio of being a primiparous cow in the high-high category compared with a primiparous cow in the low-low category increased if the sire was $\mathrm{SH} \_1, \mathrm{SH} \_2, \mathrm{SH} \_3$, or SH_6 compared with if the sire was SH_8. Likewise, the risk ratio increased if the sire was SH_1 or SH_6, compared with $\mathrm{SH} \_2, \mathrm{SH} \_3, \mathrm{SH} \_4, \mathrm{SH} \_5$, or $\mathrm{SH} \_7$.

\section{Cow Level: Associations Between CSCC Categories and Additional Explanatory Variables}

Age at calving, DIM at first milk recording, and year and month of first milk recording were also included as explanatory variables in the models on breed and sire. Detailed results on the model on associations between CSCC categories and breed are given in Supplemental 
Table 5. Distribution of primiparous cows [numbers (n) and percentages within sire], categorized into low-low, low-high, high-low, high-high, and inconclusive, depending on their cow composite somatic cell count (CSCC) at the first and second monthly milk recording after calving, within 8 sires (SH_1 to SH_8) of the Swedish Holstein ( $\mathrm{SH}$ ) breed, only including offspring from bulls that sired $\geq 1,000$ primiparous cows in the data set

\begin{tabular}{|c|c|c|c|c|c|c|c|}
\hline \multirow[b]{2}{*}{ Sire } & & \multicolumn{6}{|c|}{ CSCC category } \\
\hline & & Low-Low & Low-High & High-Low & High-High & Inconclusive & Total \\
\hline \multirow[t]{2}{*}{ SH_1 } & $\mathrm{n}$ & 849 & 108 & 356 & 404 & 279 & 1,996 \\
\hline & $\%$ & 42.5 & 5.4 & 17.8 & 20.2 & 14.0 & 100.0 \\
\hline \multirow[t]{2}{*}{ SH_2 } & $\mathrm{n}$ & 680 & 62 & 232 & 147 & 155 & 1,276 \\
\hline & $\%$ & 53.3 & 4.9 & 18.2 & 11.5 & 12.1 & 100.0 \\
\hline \multirow[t]{2}{*}{ SH_3 } & $\mathrm{n}$ & 580 & 76 & 171 & 191 & 183 & 1,201 \\
\hline & $\%$ & 48.3 & 6.3 & 14.2 & 15.9 & 15.2 & 100.0 \\
\hline \multirow[t]{2}{*}{ SH_4 } & $\mathrm{n}$ & 682 & 49 & 189 & 101 & 155 & 1,176 \\
\hline & $\%$ & 58.0 & 4.2 & 16.1 & 8.6 & 13.2 & 100.0 \\
\hline \multirow[t]{2}{*}{ SH_5 } & $\mathrm{n}$ & 942 & 102 & 227 & 133 & 213 & 1,617 \\
\hline & $\%$ & 58.3 & 6.3 & 14.0 & 8.2 & 13.2 & 100.0 \\
\hline \multirow[t]{2}{*}{ SH_6 } & $\mathrm{n}$ & 1,295 & 196 & 500 & 606 & 478 & 3,075 \\
\hline & $\%$ & 42.1 & 6.4 & 16.2 & 19.7 & 15.5 & 100.0 \\
\hline \multirow[t]{2}{*}{ SH_7 } & $\mathrm{n}$ & 1,064 & 108 & 293 & 149 & 230 & 1,844 \\
\hline & $\%$ & 57.7 & 5.9 & 15.9 & 8.1 & 12.5 & 100.0 \\
\hline \multirow[t]{2}{*}{ SH_8 } & $\mathrm{n}$ & 1,421 & 118 & 315 & 186 & 246 & 2,286 \\
\hline & $\%$ & 62.2 & 5.2 & 13.8 & 8.1 & 10.8 & 100.0 \\
\hline \multirow[t]{2}{*}{ Total } & $\mathrm{n}$ & 7,513 & 819 & 2,283 & 1,917 & 1,939 & 14,471 \\
\hline & $\%$ & 52.0 & 5.7 & 15.8 & 13.2 & 13.4 & 100 \\
\hline
\end{tabular}

Data S1 and Table S1 (https://doi.org/10.3168/jds .2020-18346). The relative risk ratio of being a primiparous cow in the high-high category compared with a primiparous cow in the low-low category increased with increasing age at calving, decreased with increasing DIM at first milk recording and if the first milk recording occurred in January-May 2014, September 2014June 2015, or August 2015-December 2016 compared with June 2014. The predicted probabilities for month and year of the first milk recording are presented in Figure 5 to illustrate variation over time.

Detailed results from the model on associations between CSCC categories and sire of the SR breed are given in Supplemental Data S2 and Table S2 (https: //doi.org/10.3168/jds.2020-18346). The relative risk ratio of being a primiparous cow in the high-high category compared with a primiparous cow in the low-low category decreased with increasing DIM at first milk recording and if the first milk recording occurred in January-May or August-December compared with in June. Detailed results from the model on associations between CSCC categories and sire of the SH breed are given in Supplemental Data S3 and Table S3 (https: //doi.org/10.3168/jds.2020-18346). The relative risk ratio of being a primiparous cow in the high-high category compared with a primiparous cow in the low-low category increased with increasing age at calving and decreased with increasing DIM at first milk recording and if the first milk recording occurred in January-May or August-December compared with in July.

\section{Herd Level: Proportion of Primiparous Cows in the 5 CSCC Categories}

As can be seen in Table 6 , the proportions of cows in each CSCC category varied markedly between herds each year. For example, the median herd proportion of low-low cows (i.e., most likely healthy cows) in 2016 was $54.2 \%$ and the IQR was between 43 and $63 \%$. During the same year, the median herd proportion of highhigh cows (i.e., most likely chronic subclinical mastitis) was $11.7 \%$, whereas the IQR was 8 to $17.9 \%$. For each year the median herd proportion of cows that could not be allocated to a CSCC category was below $15 \%$. In Figure 6, examples of within-herd patterns of CSCC categories in 25 of the farms are given.

The range in $\mathrm{CV}$ at herd level over time (i.e., between the 3 yr of study) was between 0 and 1.73 for the different CSCC categories, with the lowest mean CV for the low-low category $(0.20, \mathrm{SD} 0.13)$. The mean CV for the low-high, high-low, high-high, and inconclusive categories was 0.91 (SD 0.51), 0.49 (SD 0.33), 0.54 (SD 0.36 ), and 0.50 (SD 0.32), respectively.

\section{Herd Level: Associations Between Herd Factors and Proportion of Primiparous Cows in Different CSCC Categories}

The multivariable mixed-effect Poisson and negative binomial regression analyses showed that all herd factors investigated, except conventional and organic pro- 

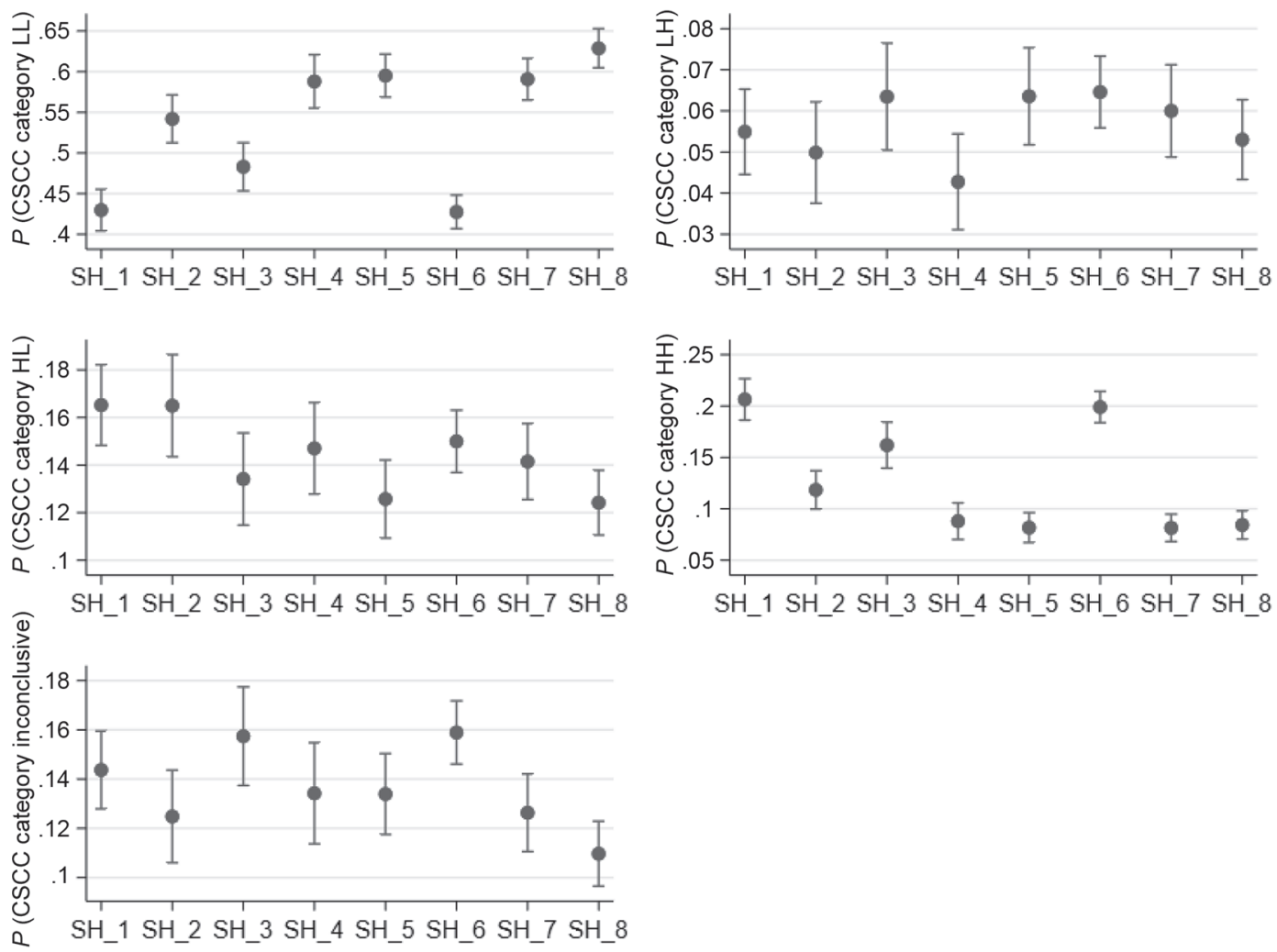

Figure 4. Predicted probabilities with 95\% CI (crossbars) for primiparous cows of 8 sires of the Swedish Holstein (SH_1 to SH_8) breed of being in a low-low (LL), low-high (LH), high-low (HL), high-high (HH) or inconclusive cow composite somatic cell count (CSCC) category, based on results from the 2 first monthly milk recordings after calving ( $\mathrm{n}=14,557$ primiparous cows in 1,286 herds). Only sires with $\geq 1,000$ offspring in the data used were included in the analysis.

duction, were significantly associated with the number of primiparous cows in a CSCC category at herd level. Detailed results are given in Table 7 and Supplemental Data S4 (https://doi.org/10.3168/jds.2020-18346).

Milking system was significantly associated with all 5 of the outcomes. For example, herds with AMS were associated with a lower number of primiparous cows in the low-low category and a higher number of primiparous cows in all the other categories than in herds with parlor/rotary or tiestall milking.

Milk production was significantly associated with all outcomes except the inconclusive category. In general, herds with a higher milk production were associated with a significantly higher number of primiparous cows in the low-low category and lower number of primiparous cows in the low-high, high-low, and high-high categories. The number of primiparous cows in the high-high category decreased with increasing herd milk yield and this difference was significant for all pairwise comparisons of the milk yield categories.

Herd size was significantly associated with all categories except the high-high and inconclusive categories.
For example, the number of primiparous cows in the low-low category was significantly lower in herds with a larger herd size (79.9-133.1 cows or $\geq 133.2$ cows) compared with herds with a small herd size $(\leq 59.7$ cows $)$ or a moderate herd size (59.8-79.8 cows).

Year was significantly associated with all categories except the low-high category. For example, the number of primiparous cows in the low-low category was significantly lower in herds in 2014 and 2015 compared with in 2016. Moreover, the number of primiparous cows in the high-high category was significantly higher in herds in 2014 and in 2015 compared with in 2016.

\section{DISCUSSION}

\section{Prevalence of Mastitis in Early-Lactation Primiparous Cows in Sweden Using Milk Recording CSCC}

As expected, the CSCC was higher at the first milk recording than at the second milk recording, and the CSCC at the first milk recording was similar or slightly 

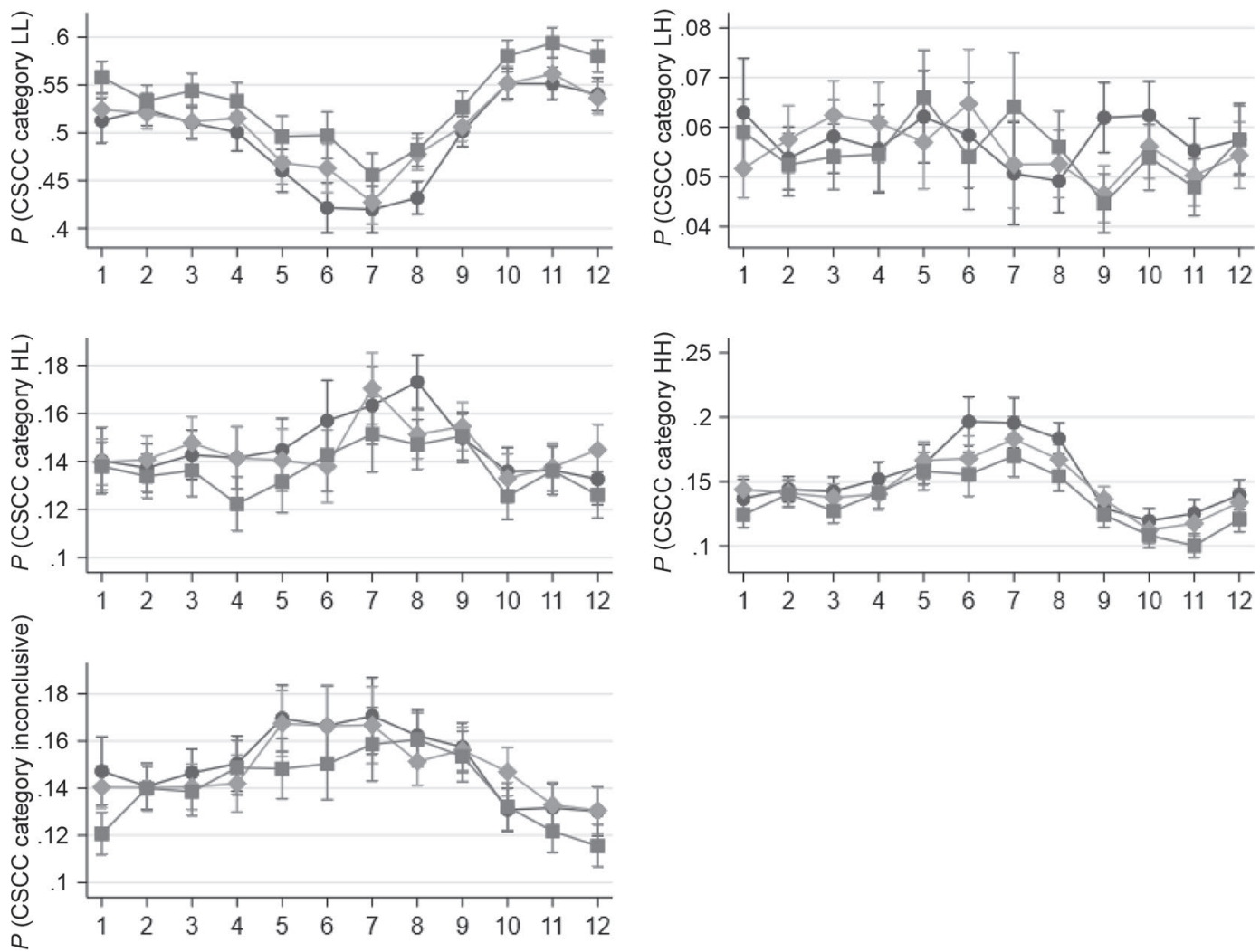

Figure 5. Predicted probabilities with 95\% CI (crossbars) over month of first milk recording (1-12) for 2014 (circles), 2015 (diamonds), and 2016 (squares) for primiparous cows being in a low-low (LL), low-high (LH), high-low (HL), high-high (HH), or inconclusive cow composite somatic cell count (CSCC) category, based on results from the 2 first monthly milk recordings after calving ( $\mathrm{n}=151,898$ primiparous cows in 1,597 herds). Please note that the scales on the y-axis differ between the graphs.

lower than those reported for primiparous cows in previous Swedish studies (Svensson et al., 2006; Nyman et al., 2009).

When evaluating udder health of early-lactation primiparous cows using CSCC categories based on milk recording CSCC, it was disturbing to find that as many as $32 \%$ of the primiparous cows were categorized as high CSCC (i.e., above 100,000 cells $/ \mathrm{mL}$ ) at the first milk recording 5 to 35 DIM, indicating IMI. The prevalence was higher than in the study by Bludau et al. (2014) where $21 \%$ of such cows were classified as high using the same cut-off. On a more positive note, ap-

Table 6. Herd distribution ( $\% ; \mathrm{n}=1,597$ herds) of primiparous cows in 5 categories based on cow composite somatic cell count (CSCC) at first and second monthly milk recording after calving in the years 2014, 2015, and 2016

\begin{tabular}{llccc}
\hline CSCC category $^{1}$ & & 2014 & 2015 & 2016 \\
\hline Low-Low & Median & 50.0 & 50.9 & 54.2 \\
& $(50 \%$ IQR & \\
Low-High & Median & $(40.0 ; 61.0)$ & $(40.5 ; 61.5)$ & $(43.0 ; 64.0)$ \\
& $(50 \%$ IQR $)$ & 4.9 & 4.7 & 4.6 \\
High-Low & Median & $(0 ; 8.3)$ & $(0 ; 8.3)$ & $(0 ; 8.0)$ \\
& $(50 \%$ IQR $)$ & 14.8 & 15.0 & 14.3 \\
High-High & Median & $(9.5 ; 20.5)$ & $(9.5 ; 20.8)$ & $(9.1 ; 19.6)$ \\
Inconclusive & $(50 \%$ IQR & 13.2 & 12.6 & 11.7 \\
& Median & $(7.7 ; 20.0)$ & $(7.7 ; 19.0)$ & $(6.7 ; 18.2)$ \\
& $(50 \% \mathrm{IQR})$ & 13.6 & 13.8 & 12.5 \\
& $(8.6 ; 18.9)$ & $(9.1 ; 18.2)$ & $(8.0 ; 17.9)$ \\
\hline
\end{tabular}

${ }^{1}$ Low $=\leq 75,000$ cells $/ \mathrm{mL} ;$ high $=>100,000$ cells $/ \mathrm{mL} ;$ inconclusive $=$ CSCC in between low and high at one or both milk recordings.

${ }^{2} \mathrm{IQR}=$ interquartile range. 
proximately half of the cows with high CSCC at the first milk recording were categorized as high-low (i.e., most likely having a transient IMI), when combining the first 2 milk recording results. This is in line with previous studies indicating that many IMI of newly calved primiparous cows disappear within a few weeks after calving (Oliver and Mitchell 1983; Aarestrup and Jensen, 1997; Valckenier et al., 2020). Moreover, only a small proportion of cows having a low CSCC at the first milk recording were later confirmed as low-high indicating IMI occurring after the first milk recording. However, the fact that almost $14 \%$ of all the cows were categorized as high-high (i.e., most likely having persistent IMI), and that only just over $50 \%$ of the cows belonged to the low-low category, indicating no IMI in early lactation, emphasizes the fact that poor udder health in early-lactation primiparous cows is an issue that should not be neglected.

Our approach to categorize udder health in earlylactation primiparous cows is new, and it may be argued that the cut-offs used were too stringent. In this study the CSCC cut-offs (low $=\leq 75,000$ cells/ $\mathrm{mL} ;$ high $=>100,000$ cells $/ \mathrm{mL}$ ) were selected based on results from our previous studies (Svensson et al., 2006;
Nyman et al., 2009, 2016; Lundberg et al., 2016) and we have previously shown that noninfected primiparous cows have a CSCC well below 75,000 cells $/ \mathrm{mL}$ independent of DIM (Nyman et al., 2014), supporting our choice of cut-offs. Although there is no consensus on the optimal CSCC cut-off, most studies use other SCC cut-offs. Often 200,000 cells/mL is used (Dohoo and Leslie 1991), but lower SCC, such as 150,000 cells/ $\mathrm{mL}$ (Santman-Berends et al., 2012) or 100,000 cells/mL (Bludau et al., 2014), have also been used especially in studies on primiparous cows, which overall have lower SCC than multiparous cows. According to SantmanBerends et al. (2012), using a similar approach as the present study for a study on primiparous cows and a CSCC of 150,000 cells/mL as the cut-off between low and high CSCC, the proportions of primiparous cows being high-high and low-low were $6 \%$ and $77 \%$, respectively. These findings differ from our results of $14 \%$ and $50 \%$, respectively, most likely due to the difference in cut-offs. Santman-Berends et al. (2012) also found that $17.6 \%$ of the primiparous cows had a CSCC above $150,000 / \mathrm{mL}$ at the first milk recording, which is similar to 14 to $17 \%$ reported in studies using $200,000 / \mathrm{mL}$ as a cut-off at first milk recording (Svensson et al., 2006;

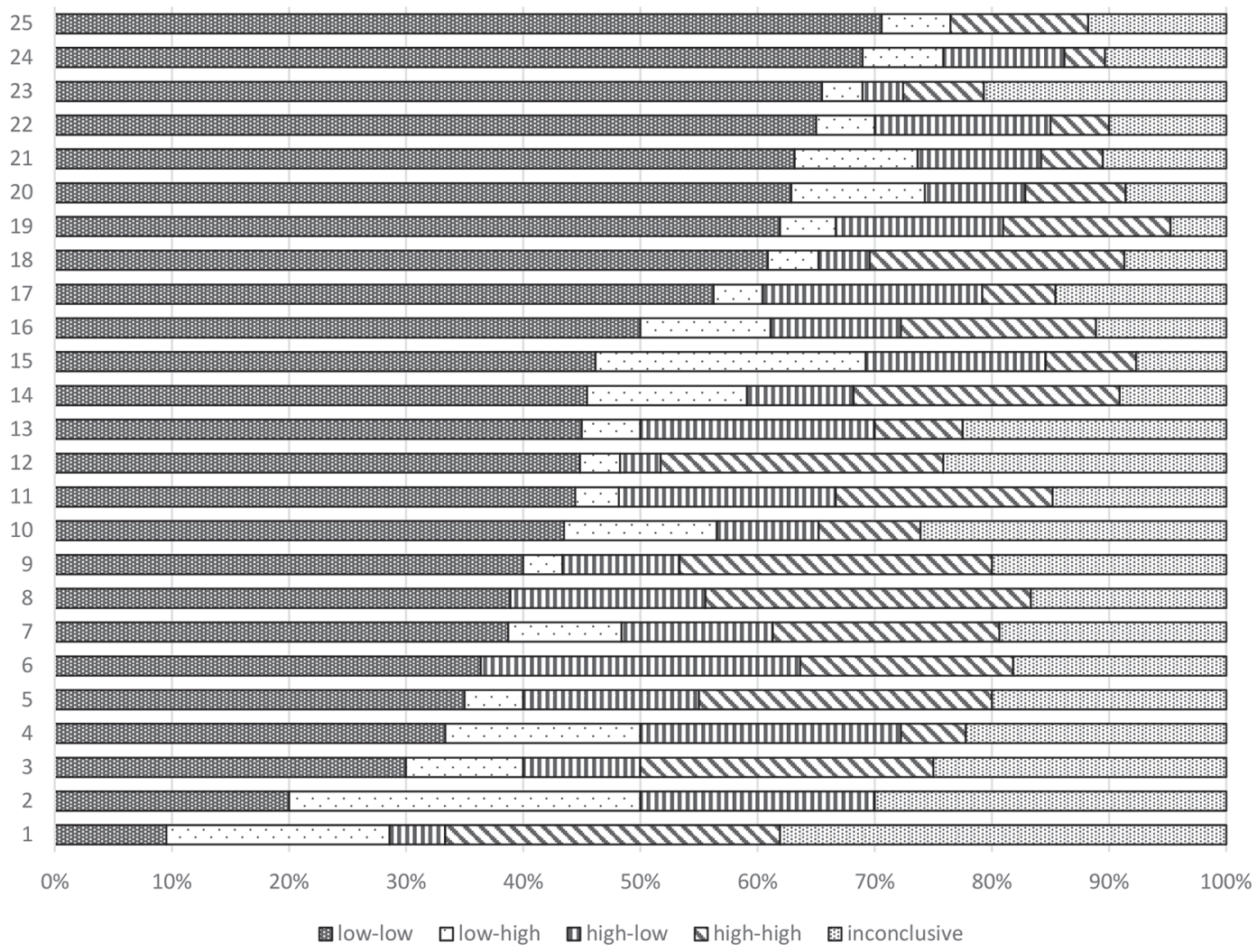

Figure 6. Examples of patterns of cow composite SCC (CSCC) categories (low-low, low-high, high-low, high-high, inconclusive) for primiparous cows in 25 randomly selected farms among 1,597 farms included in the study. Low $=\leq 75,000$ cells $/ \mathrm{mL}$, high $=>100,000$ cells $/ \mathrm{mL}$, inconclusive $=\mathrm{CSCC}$ in between low and high in one or both of the first 2 monthly milk recordings after calving. 
Table 7. Results from the final mixed-effect multivariable Poisson or negative binomial regression models, after a backward selection process, of association between herd characteristics and number of primiparous cows, with total number of primiparous cows within each herd as exposure, categorized as being low-low, low-high, high-low, high-high, or inconclusive considering the cow composite SCC at the 2 first monthly milk recordings after calving, including herd as random effect $(\mathrm{n}=4,524 \text { observation from a total of } 1,508 \text { dairy herds })^{1}$

\begin{tabular}{|c|c|c|c|c|c|}
\hline Item & $\beta$ & $\mathrm{SE}(\beta)$ & IRR & CI (IRR) & $P$-value \\
\hline \multicolumn{6}{|c|}{ Model for association with proportion of primiparous cows in the low-low category } \\
\hline Intercept & -0.82 & 0.02 & & & \\
\hline \multicolumn{6}{|l|}{ Milking system } \\
\hline AMS & Referent & & & & \\
\hline Parlor or rotary & 0.21 & 0.01 & 1.23 & $1.20 ; 1.26$ & $<0.001$ \\
\hline Tiestall & 0.21 & 0.01 & 1.24 & $1.20 ; 1.28$ & $<0.001$ \\
\hline \multicolumn{6}{|l|}{ Herd size, number of cows } \\
\hline$<59.8$ & Referent & & & & \\
\hline $59.8-79.8$ & -0.03 & 0.01 & 0.97 & $0.94 ; 1.01$ & 0.32 \\
\hline $79.9-133.1$ & -0.07 & 0.02 & 0.94 & $0.90 ; 0.97$ & $<0.001$ \\
\hline$\geq 133.2$ & -0.07 & 0.02 & 0.93 & $0.89 ; 0.96$ & $<0.001$ \\
\hline \multicolumn{6}{|l|}{ Milk production, $\mathrm{kg}$ of ECM } \\
\hline$<9,398$ & Referent & & & & \\
\hline $9,398-10,128$ & 0.08 & 0.01 & 1.08 & $1.05 ; 1.11$ & $<0.001$ \\
\hline $10,129-10,803$ & 0.11 & 0.01 & 1.12 & $1.09 ; 1.15$ & $<0.001$ \\
\hline$\geq 10,804$ & 0.15 & 0.01 & 1.16 & $1.13 ; 1.19$ & $<0.001$ \\
\hline \multicolumn{6}{|l|}{ Year } \\
\hline 2014 & -0.05 & 0.01 & 0.95 & $0.93 ; 0.97$ & $<0.001$ \\
\hline 2015 & -0.04 & 0.01 & 0.96 & $0.95 ; 0.98$ & $<0.001$ \\
\hline 2016 & Referent & & & & \\
\hline Estimated variance of herd random effect & 0.01 & 0.001 & & & \\
\hline \multicolumn{6}{|c|}{ Model for association with proportion of primiparous cows in the low-high category } \\
\hline Intercept & -2.72 & 0.06 & & & \\
\hline \multicolumn{6}{|l|}{ Milking system } \\
\hline AMS & Referent & & & & \\
\hline Parlor or rotary & -0.32 & 0.03 & 0.72 & $0.68 ; 0.77$ & $<0.001$ \\
\hline Tiestall & -0.36 & 0.04 & 0.70 & $0.64 ; 0.76$ & $<0.001$ \\
\hline \multicolumn{6}{|l|}{ Herd size, number of cows } \\
\hline$<59.8$ & Referent & & & & \\
\hline $59.8-79.8$ & 0.09 & 0.05 & 1.10 & $0.99 ; 1.21$ & 0.23 \\
\hline $79.9-133.1$ & 0.11 & 0.05 & 1.12 & $1.01 ; 1.24$ & 0.10 \\
\hline$\geq 133.2$ & 0.15 & 0.05 & 1.16 & $1.04 ; 1.29$ & 0.02 \\
\hline \multicolumn{6}{|l|}{ Milk production, $\mathrm{kg}$ of ECM } \\
\hline$<9,398$ & Referent & & & & \\
\hline $9,398-10,128$ & -0.09 & 0.04 & 0.91 & $0.85 ; 0.98$ & 0.03 \\
\hline $10,129-10,803$ & -0.17 & 0.04 & 0.85 & $0.79 ; 0.91$ & $<0.001$ \\
\hline$>10,804$ & -0.18 & 0.04 & 0.83 & $0.77 ; 0.89$ & $<0.001$ \\
\hline Estimated variance of herd random effect & 0.04 & 0.01 & & & \\
\hline \multicolumn{6}{|c|}{ Model for association with proportion of primiparous cows in the high-low category } \\
\hline Intercept & -1.79 & 0.03 & & & \\
\hline \multicolumn{6}{|l|}{ Milking system } \\
\hline AMS & Referent & & & & \\
\hline Parlor or rotary & -0.22 & 0.02 & 0.80 & $0.77 ; 0.83$ & $<0.001$ \\
\hline Tiestall & -0.19 & 0.03 & 0.83 & $0.78 ; 0.87$ & $<0.001$ \\
\hline \multicolumn{6}{|l|}{ Herd size, number of cows } \\
\hline$<59.8$ & Referent & & & & \\
\hline $59.8-79.8$ & 0.01 & 0.03 & 1.01 & $0.95 ; 1.07$ & 1.00 \\
\hline $79.9-133.1$ & 0.09 & 0.03 & 1.09 & $1.03 ; 1.16$ & 0.01 \\
\hline$\geq 133.2$ & 0.12 & 0.03 & 1.13 & $1.06 ; 1.20$ & $<0.001$ \\
\hline \multicolumn{6}{|l|}{ Milk production, $\mathrm{kg}$ of ECM } \\
\hline$<9,398$ & Referent & & & & \\
\hline $9,398-10,128$ & -0.06 & 0.02 & 0.94 & $0.91 ; 0.98$ & 0.02 \\
\hline $10,129-10,803$ & -0.08 & 0.02 & 0.92 & $0.88 ; 0.96$ & $<0.001$ \\
\hline$\geq 10,804$ & -0.13 & 0.02 & 0.88 & $0.84 ; 0.92$ & $<0.001$ \\
\hline \multicolumn{6}{|l|}{ Year } \\
\hline 2014 & 0.04 & 0.02 & 1.04 & $1.00 ; 1.07$ & 0.06 \\
\hline 2015 & 0.05 & 0.02 & 1.05 & $1.01 ; 1.08$ & 0.008 \\
\hline 2016 & Referent & & & & \\
\hline Estimated variance of herd random effect & 0.02 & 0.003 & & & \\
\hline
\end{tabular}


Table 7 (Continued). Results from the final mixed-effect multivariable Poisson or negative binomial regression models, after a backward selection process, of association between herd characteristics and number of primiparous cows, with total number of primiparous cows within each herd as exposure, categorized as being low-low, low-high, high-low, high-high, or inconclusive considering the cow composite SCC at the 2 first monthly milk recordings after calving, including herd as random effect ( $\mathrm{n}=4,524$ observation from a total of 1,508 dairy herds) ${ }^{1}$

\begin{tabular}{|c|c|c|c|c|c|}
\hline Item & $\beta$ & $\mathrm{SE}(\beta)$ & IRR & CI (IRR) & $P$-value \\
\hline \multicolumn{6}{|c|}{ Model for association with proportion of primiparous cows in the high-high category } \\
\hline Intercept & -1.81 & 0.03 & & & \\
\hline \multicolumn{6}{|l|}{ Milking system } \\
\hline AMS & Referent & & & & \\
\hline Parlor or rotary & -0.18 & 0.02 & 0.84 & $0.80 ; 0.88$ & $<0.001$ \\
\hline Tiestall & -0.26 & 0.03 & 0.77 & $0.73 ; 0.82$ & $<0.001$ \\
\hline \multicolumn{6}{|l|}{ Milk production, $\mathrm{kg}$ of ECM } \\
\hline$<9,398$ & Referent & & & & \\
\hline $9,398-10,128$ & -0.12 & 0.02 & 0.89 & $0.85 ; 0.93$ & $<0.001$ \\
\hline $10,129-10,803$ & -0.17 & 0.03 & 0.84 & $0.80 ; 0.88$ & $<0.001$ \\
\hline$\geq 10,804$ & -0.26 & 0.03 & 0.77 & $0.73 ; 0.82$ & $<0.001$ \\
\hline \multicolumn{6}{|l|}{ Year } \\
\hline 2014 & 0.09 & 0.02 & 1.10 & $1.06 ; 1.14$ & $<0.001$ \\
\hline 2015 & 0.05 & 0.02 & 1.05 & $1.01 ; 1.09$ & 0.01 \\
\hline 2016 & Referent & & & & \\
\hline Estimated variance of herd random effect & 0.08 & 0.007 & & & \\
\hline \multicolumn{6}{|c|}{ Model for association with proportion of primiparous cows in the inconclusive category } \\
\hline Intercept & -1.90 & 0.02 & & & \\
\hline \multicolumn{6}{|l|}{ Milking system } \\
\hline AMS & Referent & & & & \\
\hline Parlor or rotary & -0.16 & 0.02 & 0.85 & $0.83 ; 0.88$ & $<0.001$ \\
\hline Tiestall & -0.20 & 0.02 & 0.82 & $0.78 ; 0.86$ & $<0.001$ \\
\hline \multicolumn{6}{|l|}{ Year } \\
\hline 2014 & 0.05 & 0.02 & 1.06 & $1.02 ; 1.09$ & 0.003 \\
\hline 2015 & 0.04 & 0.02 & 1.04 & $1.01 ; 1.08$ & 0.03 \\
\hline 2016 & Referent & & & & \\
\hline Estimated variance of herd random effect & 0.01 & 0.003 & & & \\
\hline
\end{tabular}

${ }^{1}$ The $P$-values were Bonferroni adjusted. AMS $=$ automatic milking system; IRR $=$ incidence rate ratio.

Nyman et al., 2009; Frössling et al., 2017; Naqvi et al., 2018). The choice of cut-off depends on the purpose of the study, and because we wanted to find the majority of the truly noninfected and infected primiparous cows, we chose the present cut-off. Moreover, because the distribution of udder pathogens and the breeding material may differ markedly between countries, we believe that the use of data retrieved from Swedish studies was most appropriate.

\section{Associations Between CSCC Categories and Cow Factors}

The analyses revealed some interesting associations between CSCC categories and breed and sire of the primiparous cows, as well as between categories and age at calving and season.

First, the results indicate that primiparous cows of the Jersey breed were more prone for high CSCC in early lactation than the main Swedish dairy breeds $\mathrm{SH}$ and SR. The reasons for this breed difference are not clear and studies comparing udder health of Jersey, $\mathrm{SH}$ and SR are scarce. In addition, SH primiparous cows had a lower risk to be categorized as high-high than SR cows, which is in contrast to earlier studies showing that Swedish SH cows, in general, have higher CSCC than SR cows (Frössling et al., 2017; Nyman et al., 2009; Persson Waller et al., 2009).

Both among SH and SR sires included in the study it was clear that the sires differed in their association with CSCC categories of primiparous cow indicating a genetic effect on this variable, which might be worthwhile to investigate further. For example, the daughters of sire SR_3 had better udder health than the daughters of the other SR sires. In line with this, this sire had one of the highest breeding indexes (data not shown; www.vikinggenetics.se) for SCC in first lactation. However, SR_6 had a similar breeding index as SR_3, whereas the proportions of cows in the CSCC categories indicated a markedly poorer udder health. As already mentioned, the daughters of the SH sires also differed markedly, the daughters of sires SH_1 and SH_6 had poorer udder health than daughters of the other sires as shown by a lower proportion of daughters with a low-low SCC and higher proportion of daughters with a high-high SCC. Overall, the results for SH sires 
followed the breeding indexes for SCC in first lactation well (data not shown; www.vikinggenetics.se). In line with our studies, Narayana et al. (2018) found genetic variation among Holstein sires of importance for subclinical mastitis in primiparous cows.

As mentioned earlier, we also found that the risk to be in the high-high category increased with increasing age at calving. The reasons for this are not clear and few comparable studies are available. However, Bludau et al. (2014) found that a higher proportion of primiparous cows calving at $>37$ mo of age had CSCC $\geq 100,000$ cells $/ \mathrm{mL}$ at the first test day than cows calving at a younger age, although this variable was not included in the final model. In contrast, De Vliegher et al. (2004) found that primiparous cows in herds with an average calving age over 27 mo had lower SCC between DIM 5 and 14 than cows in herds with a lower calving age. Moreover, the results also indicated a seasonal effect as more primiparous cows were categorized as high-high at first milk recording during summer (June to August). A seasonal effect on CSCC in primiparous cows has been reported before (De Vliegher et al., 2004; Olde Riekerink et al., 2007; Bludau et al., 2014), but studies are difficult to compare (e.g., due to different study designs).

\section{Herd Prevalence of Mastitis in Early-Lactation Primiparous Cows Using Milk Recording CSCC}

The proportion of different CSCC categories in earlylactation primiparous cows varied markedly among herds, which is similar to the findings of SantmanBerends et al. (2012), although they used different CSCC cut-offs. As indicated by the range in $\mathrm{CV}$ at herd level over time, however, the herd CSCC categories, especially the low-low category, were stable over the 3-yr period studied. This stability/consistency in udder health probably derives from a consistency in management and housing factors, indicating that this categorization can be used to identify success and problem herds for udder health in this group of cows.

The results also revealed that only a small proportion of the herds managed to keep all, or almost all, of their early-lactation primiparous cows healthy (i.e., in the low-low category). Overall, the median proportion of low-low cows was around $50 \%$ in the herds indicating a need for improvement of the management of these animals. To investigate why some herds are more successful than other herds, studies on risk factors for high CSCC in early lactation are needed. As already mentioned, our results indicate that the CSCC categories can be used for selection of herds for such studies. Indeed, such a study on risk and success factors in heif- ers and early-lactation primiparous cows has recently been performed on Swedish farms and results will be presented shortly.

\section{Associations Between Herd Factors and CSCC Categories}

In this study, milking system, milk production, herd size, and year, but not production system, were significantly associated with the proportion of primiparous cows in different CSCC categories.

The fact that herds with AMS had a lower proportion of primiparous cows in the low-low category and a higher proportion of primiparous cows in the highhigh category compared with herds with other milking systems is in line with Swedish herds with AMS having higher herd SCC than herds with conventional milking systems (Anonymous, 2017a). Some risk factors explaining why the udder health may be poorer in AMS herds have been identified (e.g., Hovinen et al., 2009; Dohmen et al., 2010), but the results from the present study indicate that important differences in management between AMS herds and other herds may be present also for heifers before calving. For example, it may be hypothesized that problems related to the introduction of heifers to the AMS can be of importance, but further studies are needed to investigate this theory.

The fact that herds with a higher milk production have a higher proportion of primiparous cows in the low-low category are also in line with previous findings that Swedish herds with high production have lower bulk milk SCC (A. Nyman, personal communication). Good udder health among cows and good routines are prerequisites for high milk production. It is likely that herds with high milk production also have good management of the heifers and early-lactation primiparous cows.

In this study we found that herds with less than 80 cows had a higher proportion of first-parity cows in the low-low category and a lower proportion of cows in the high-high category than larger herds. One explanation for this difference is that lower herd size means reduced risk for spread of infectious agents. It is also likely that the management of individual animals is easier in smaller herds. The results are also in line with previous findings that the overall bulk milk SCC is lower in smaller herds (A. Nyman, personal communication; Anonymous, 2017a).

We also found a difference between years of study, the results indicate that udder health in early-lactation primiparous cows improved over time, which is a positive finding. The reasons for this improvement are not 
known but were not reflected in a decline of the national bulk milk SCC during the years of study (Anonymous, 2017b).

\section{Methodological Considerations}

As this study required access to herd and cow data on production and CSCC, it was only possible to include herds affiliated to the SOMRS. At the time of the study, however, approximately $75 \%$ of the Swedish dairy herds and $80 \%$ of the dairy cows were affiliated to this scheme (Anonymous, 2016, 2017a), so the majority of Swedish herds and cows were included in the study. To get a sufficient number of primiparous cows per herd, we decided to only include herds with at least 10 primiparous cows per year. Not surprisingly this inclusion criterion meant that the selected herds had a larger herd size than the average of the herds in the SOMRS (108-111 cows/herd vs. 80-87 cows/herd per year; Anonymous 2016, 2017a). Moreover, the selected herds in the present study also had a slightly higher annual milk production compared with all herds in the $\operatorname{SOMRS}(9,878,10,040$, and 10,254 $\mathrm{kg}$ of ECM vs. 9,721, 9,903, and 10,122 kg of ECM for years 2014, 2015, and 2016, respectively; Anonymous 2016, 2017a). This is in line with Swedish data showing that larger herds also have higher milk production (Anonymous 2016, 2017a). In addition, the proportion of herds with a loose housing system was higher (63\% vs. $47 \%$ ) than in the whole population, which is probably due to Swedish herds with a loose housing system having more cows than herds with tiestalls. Despite the above, we believe that the study had high precision and high validity because we included all herds affiliated to the SOMRS with at least 10 primiparous cows per year.

\section{CONCLUSIONS}

The prevalence of mastitis in early-lactation primiparous cows in Sweden, indicated by CSCC categorization of the 2 first monthly milk recordings after calving, was high. Only $50 \%$ of the primiparous cows were considered noninfected based on the CSCC cutoffs used. Significant associations were found between CSCC categories and the cow factors breed and sire, indicating reduced udder health in some breeds and in daughters of some sires. The proportions of cows in different CSCC categories varied markedly between herds and significant associations were found between CSCC categories and herd size, herd milk production, milking system, and year. Overall, the results emphasize the need for prevention of subclinical mastitis in earlylactation primiparous cows and indicate that CSCC categories may be a useful tool for identifying success and problem herds.

\section{ACKNOWLEDGMENTS}

Financial support from the Swedish Farmers' Foundation for Agricultural Research (Stockholm, Sweden) is gratefully acknowledged. The authors have not stated any conflicts of interest.

\section{REFERENCES}

Aarestrup, F. M., and N. E. Jensen. 1997. Prevalence and duration of intramammary infection in Danish heifers during the peripartum period. J. Dairy Sci. 80:307-312. https://doi.org/10.3168/jds .S0022-0302(97)75939-3.

Anonymous. 2016. Husdjursstatistik 2016 [Cattle statistics 2016], Växa Sverige, Uppsala, Sweden, 1-39.

Anonymous. 2017a. Husdjursstatistik 2017 [Cattle statistics 2017], Växa Sverige, Uppsala, Sweden, 1-39.

Anonymous. 2017b. Redogörelse för husdjursorganisationernas djurhälsovård 2016/2017 [Account of animal health care by animal health organisations 2016/2017], Växa Sverige, Uppsala, Sweden, $1-49$.

Bludau, M. J., A. Maeschli, F. Leiber, A. Steiner, and P. Klocke. 2014. Mastitis in dairy heifers: Prevalence and risk factors. Vet. J. 202:566-572. https://doi.org/10.1016/j.tvjl.2014.09.021.

De Vliegher, S., L. K. Fox, S. Piepers, S. McDougall, and H. W. Barkema. 2012. Invited review: Mastitis in dairy heifers: Nature of the disease, potential impact, prevention, and control. J. Dairy Sci. 95:1025-1040. https://doi.org/10.3168/jds.2010-4074.

De Vliegher, S., H. Laevens, H. W. Barkema, I. R. Dohoo, H. Stryhn, G. Opsomer, and A. de Kruif. 2004. Management practices and heifer characteristics associated with early lactation somatic cell count of Belgian dairy heifers. J. Dairy Sci. 87:937-947. https:// doi.org/10.3168/jds.S0022-0302(04)73238-5.

Dohmen, W., F. Neijenhuis, and H. Hogeveen. 2010. Relationship between udder health and hygiene on farms with automatic milking system. J. Dairy Sci. 93:4019-4033. https://doi.org/10.3168/jds .2009-3028.

Dohoo, I., W. Martin, and H. Stryhn. 2010. Veterinary Epidemiologic Research. 2nd ed. VER Inc, Charlottetown, Prince Edward Islands, Canada.

Dohoo, L. R., and K. E. Leslie. 1991. Evaluation of changes in somatic cell counts as indicators of new intramammary infections. Prev. Vet. Med. 10:225-237. https://doi.org/10.1016/0167 $-5877(91) 90006-\mathrm{N}$.

Fox, L. K. 2009. Prevalence, incidence and risk factors of heifer mastitis. Vet. Microbiol. 134:82-88. https://doi.org/10.1016/j.vetmic 2008.09.005.

Frössling, J., A. Ohlson, and C. Hallén Sandgren. 2017. Incidence and duration of increased somatic cell count in Swedish dairy cows and associations with milking system type. J. Dairy Sci. 100:73687378. https://doi.org/10.3168/jds.2016-12333.

Hagnestam, C., U. Emanuelson, and B. Berglund. 2007. Yield losses associated with clinical mastitis occurring in different weeks of lactation. J. Dairy Sci. 90:2260-2270. https://doi.org/10.3168/jds .2006-583.

Hovinen, M., M. D. Rasmussen, and S. Pyörälä. 2009. Udder health of cows changing from tie stalls or free stalls with conventional milking to free stalls with either conventional or automatic milking. J. Dairy Sci. 92:3696-3703. https://doi.org/10.3168/jds.2008-1962.

Lundberg, Å., A.-K. Nyman, A. Aspán, S. Börjesson, H. Ericsson Unnerstad, and K. Persson Waller. 2016. Udder infections with Staphylococcus aureus, Streptococcus dysgalactiae, and Streptococcus uberis at calving in dairy herds with suboptimal udder health. J. Dairy Sci. 99:2102-2117. https://doi.org/10.3168/jds.2015-9487. 
Naqvi, S. A., J. de Buck, S. Dufour, and H. W. Barkema. 2018. Udder health in Canadian dairy heifers during early lactation. J. Dairy Sci. 101:3233-3247. https://doi.org/10.3168/jds.2017-13579.

Narayana, S. G., F. Miglior, S. A. Naqvi, F. Malchiodi, P. Martin, and H. W. Barkema. 2018. Genetic analysis of subclinical mastitis in early lactation of heifers using both linear and threshold models. J. Dairy Sci. 101:11120-11131. https://doi.org/10.3168/jds.2018 $-15126$.

Nyman, A.-K., T. Ekman, U. Emanuelson, A. H. Gustafsson, K. Holtenius, K. Persson Waller, and C. Hallén Sandgren. 2007. Risk factors associated with the incidence of veterinary-treated clinical mastitis in Swedish dairy herds with a high milk yield and a low prevalence of subclinical mastitis. Prev. Vet. Med. 78:142-160. https://doi.org/10.1016/j.prevetmed.2006.10.002.

Nyman, A.-K., U. Emanuelson, A. H. Gustafsson, and K. Persson Waller. 2009. Management practices associated with udder health of first-parity dairy cows in early lactation. Prev. Vet. Med. 88:138-149. https://doi.org/10.1016/j.prevetmed.2008.08.005.

Nyman, A.-K., U. Emanuelson, and K. Persson Waller. 2016. Diagnostic test performance of somatic cell count, lactate dehydrogenase, and $\mathrm{N}$-acetyl- $\beta$-D-glucosaminidase for detecting dairy cows with intramammary infection. J. Dairy Sci. 99:1440-1448. https://doi .org/10.3168/jds.2015-9808.

Nyman, A.-K., K. Persson Waller, T. W. Bennedsgaard, T. Larsen, and U. Emanuelson. 2014. Associations of udder-health indicators with cow factors and with intramammary infection in dairy cows. J. Dairy Sci. 97:5459-5473. https://doi.org/10.3168/jds.2013 $-7885$.

Olde Riekerink, R. G. M., H. W. Barkema, and H. Stryhn. 2007. The effect of season on somatic cell count and the incidence of clinical mastitis. J. Dairy Sci. 90:1704-1715. https://doi.org/10.3168/jds $.2006-567$.
Oliver, S. P., and B. A. Mitchell. 1983. Intramammary infections in primigravid heifers near parturition. J. Dairy Sci. 66:1180-1183. https://doi.org/10.3168/jds.S0022-0302(83)81916-X.

Persson Waller, K., B. Bengtsson, A. Lindberg, A. Nyman, and H. Ericsson Unnerstad. 2009. Incidence of mastitis and bacterial findings at clinical mastitis in Swedish primiparous cows - Influence of breed and stage of lactation. Vet. Microbiol. 134:90-97. https:// doi.org/10.1016/j.vetmic.2008.09.004.

Santman-Berends, I. M. G. A., R. G. M. Olde Riekerink, O. C. Sampimon, G. van Schaik, and T. J. G. M. Lam. 2012. Incidence of subclinical mastitis in Dutch dairy heifers in the first 100 days in lactation and associated risk factors. J. Dairy Sci. 95:2476-2484. https://doi.org/10.3168/jds.2011-4766.

Svensson, C., A.-K. Nyman, K. Persson Waller, and U. Emanuelson. 2006. Effects of housing, management, and health of dairy heifers on first-lactation udder health in southwest Sweden. J. Dairy Sci. 89:1990-1999. https://doi.org/10.3168/jds.S0022-0302(06)72266 -4 .

Valckenier, D., S. Piepers, A. De Visscher, and S. De Vliegher. 2020. The effect of intramammary infection in early lactation with nonaureus staphylococci in general and Staphylococcus chromogenes specifically on quarter milk somatic cell count and quarter milk yield. J. Dairy Sci. 103:768-782. https://doi.org/10.3168/jds.2019 $-16818$

\section{ORCIDS}

K. Persson Waller @ https://orcid.org/0000-0002-8481-4313

A.-K. Nyman @ https://orcid.org/0000-0002-6643-0404 